\title{
PERAN KLÈBUN BABINE' DALAM UPAYA PENCEGAHAN PERNIKAHAN USIA DINI DI DESA PONTEH KECAMATAN GALIS KABUPATEN PAMEKASAN
}

\author{
Hoiril Sabariman \\ Universitas Brawijaya Malang \\ Email: hoirilsabariman@student.ub.ac.id
}

\section{ABSTRAK}

Pencegahan kasus pernikahan usia dini di Desa Ponteh berjalan optimal. Penelitian ini fokus pada peran Klèbun Babine' (perempuan kepala desa) dalam pencegahan kasus pernikahan usia dini di Desa Ponteh. Pendekatan studi kasus pengamatan langsung dan wawancara mendalam digunakan untuk memahami fenomena tersebut. Dalam menjelaskan peran Klèbun Babine' ada dua teori yang digunakan yaitu teori strukturalis dan teori interaksionis. Artikel ini menyimpulkan Klèbun Babine' menjadi figur yang dapat dicontoh oleh remaja perempuan di desa. Cara kerja Klèbun Babine' dalam mencegah kasus pernikahan usia dini, pertama tidak memberikan rekomendasi dari desa untuk anak dibawah umur. Kedua pendekatan secara multidimensional untuk penundaan pernikahan usia dini. Ketiga, melakukan penyadaran kepada masyarakat dengan memanfaatkan berbagai kegiatan desa. Keempat, sosialisasi tentang kesehatan reproduksi remaja secara terpadu. Kontribusi artikel ini bahwa peran Klèbun Babine' bisa menjadi model bagi kepala desa dalam pengentasan pernikahan dini di daerah Madura dan daerah yang lain.

Kata kunci: Peran, Klèbun Babine', Pernikahan

Dini, Pedesaan 


\section{ABSTRACT}

Prevention of early childhood marriage in Ponteh village runs optimally. This research focuses on the role of Klèbun Babine' (village headwoman) in the prevention of early childhood marriage in Ponteh village. The case study approach direct observation and in-depth interviews are used to understand the phenomenon. Two theories namely structuralist and interactionist theories are used in explaining the role of Klèbun Babine'. This article concludes that Klèbun Babine' is a figure that can be emulated by young women in the village. The first role of Klèbun Babine' in preventing cases of early childhood marriage is not to provide recommendations from the village for minors. The second one is to take a multidimensional approach to delaying early childhood marriage The third one is to raise awareness to the community by utilizing various village activities. The last one is to disseminate information on adolescent reproductive health in an integrated way. The scientific contribution of this article is that the role of Klèbun Babine' can be a model for other village heads in the alleviation of early marriage in the village of Ponteh Madura and other regions.

Keywords: Role, Village Headwomen, Early Marriage, Rural

\section{A. Pendahuluan}

Jumlah pernikahan usia dini di Indonesia masih tinggi. Menurut data Kementrian Pemberdayaan Perempuan dan Perlindungan Anak (Kemen PPPA) (2018) Indonesia termasuk negara dengan persentase pernikahan usia dini tinggi dengan rangking 37 di dunia, dan tertinggi kedua di Asia Tenggara. Data yang sama dipaparkan oleh Badan Pusat Statistik (2016) mencatat 11,13\% perempuan menikah di usia 10-15 tahun dan sekitar 32,10\% kawin di usia 16-18 tahun. Beberapa data ini menjadikan Indonesia 
masuk dalam kategori darurat perkawinan anak. Tingginya perkawinan anak di Indonesia berpengaruh terhadap Indeks Pembangunan Manusia (IPM) dan Indeks Kedalaman Kemiskinan (IKK).

Berdasarkan penelitian Pusat Studi Kebijakan Kependudukan UGM (2014) ada lima faktor utama penyebab perkawinan usia anak. Pertama, Kemiskinan, dimana peluang keluarga tidak mampu/miskin untuk mengawinkan anaknya di usia dini, tiga kali lebih tinggi daripada keluarga yang mampu/berkecukupan. Kedua, Tingkat Pendidikan Orang tua yang rendah terdapat hubungan kuat antara status ekonomi keluarga, pendidikan orang tua dan pekerjaannya terhadap anak-anak yang dikawinkan lebih dini. Semakin tinggi pendidikan orang tua, maka akan semakin besar untuk menunda pernikahan anak. Begitu juga sebaliknya. Ketiga, Tradisi Setempat, hal ini berhubungan dengan pengaruh adat istiadat, nilai, kebiasaan, norma, kepercayaan masyarakat dalam hal perkawinan. Keempat, Perubahan tata nilai yang ada dalam masyarakat, Anak-anak sekarang lebih permisif terhadap calon pasangannya (seks bebas dan kehamilan yang tidak dikehendaki) misalnya $70 \%$ perkawinan anak terjadi di Wonogiri pada tahun 2011, akibat seks bebas dan kehamilan yang tidak dikehendaki, begitu juga di Kabupaten Pasuruan. Kelima, Kurangnya kesadaran dan pemahaman anak perempuan dan pengaruh sosial media (31,9\%) anak yang menikah di bawah umur tidak tahu jika sekali berhubungan seksual dapat hamil, begitu juga informasi dari media sosial tentang pendidikan seks/ masalah kesehatan kurang komprehensif, memicu perilaku menyimpang dan berujung pada perkawinan usia sekolah. Hal yang sama dijelaskan oleh (Rosalin: 2018; Rumekti, 2016; Djamilah, 2014; Fajarina 2011) tentang penyebab pernikahan usia dini. 
Senada dengan paparan di atas, Mulia (2018) menyebut penyebab pernikahan usia dini ada tiga hal. Pertama, ketimpangan status gender di masyarakat yang merendahkan posisi remaja perempuan. Kedua, kurangnya pengetahuan tentang resiko kesehatan organ reproduksi remaja perempuan yang terjadi akibat perkawinan muda. Ketiga, daerah yang rawan konflik, karena runtuhnya struktur hukum, ekonomi dan sosial. Sedangkan Salim (2018) menjelaskan tentang penyebab masih tingginya pernikahan usia dini di Indonesia dipengaruhi empat faktor. Pertama, faktor pendidikan yang minim mengakibatkan remaja lebih rentan terhadap kehamilan. Kedua, faktor ekonomi yang rendah membuat perkawinan anak meningkat. ketiga, faktor sosiokultural yang tejadi di sebagian besar masyarakat Indonesia menganggap bahwa perawan tua masih menjadi ketakutan, sehingga menikahkan anak dianggap sebagai solusi. Keempat, faktor agama dalam kelompok tertentu menganggap nikah pada usia dini itu wajar, dengan dalil untuk menghindari zina.

Dalam menanggulangi pernikahan usia dini, pemerintah membuat kebijakan untuk pendewaasaan usia perkawinan anak. Adapun program yang dilakukan pemerintah antara lain; program belajar 12 tahun, sosialisasi pentingnya pendidikan kesehatan reproduksi (kespro) oleh penyuluh (PP No. 61 tahun 2014 tentang kespro), program KB dan generasi berencana, Pengarusutamaan gender dalam pembangunan nasional dan konsep KKG, program Kabupaten/kota layak anak, revisi UU nomer 1 tahun 1974 yang masuk dalam Prolegnas 2015-2019. Kemudian perbaikan RUU kesetaraan gender, sosialisasi UU Nomer 35 tahun 2014 tentang perubahan UU nomer 23 tahun 2002 tentang perlindungan anak, kerjasama dengan organisasi perempuan, organisasi keagamaan dan organisasi sosialisasi pendewasaan usia perkawinan, peraturan 
menteri pemberdayaan perempuan dan perlindungan anak nomer 6 tahun 2013 tentang pembangunan keluarga, sosialisasi tentang "parenting skill", menyediakan programprogram pengentasan kemiskinan dan pemberdayaan UKM keluarga miskin dan yang terakhir adalah pembuatan Perda untuk pencegahan perkawinan anak (Laporan, 2018).

Upaya pencegahan pernikahan usia dini di Indonesia setidaknya dijelaskan oleh Suhadi (2018), Dema (2018), Sudibia(2015) Kabang (2018). Menurut Suhadi (Kabang et al., 2018) upaya pencegahan dilakukan dengan inisiasi program pendampingan melalui pembentukan kelompok masyarakat sadar hukum (KADARKUM). Program KADARKUM ini perlu sosialisasi aturan hukum, pemberian informasi, dokumen, konsultasi serta pendampingan penanganan perkara terhadap beberapa pencerian atau kasus lain yang disebabkan oleh pernikahan usia dini. Selain itu, perlu adanya partisipasi antara pemerintah dan partisipasi masyarakat terhadap penanggulangan pernikahan usia dini (Herman \& Sarinah, 2018).

Dalam riset Kabang (Kabang et al., 2018), teknik diskusi dalam layanan informasi cukup efektif dalam mengurangi pernikahan usia dini dengan memberikan pemahaman tentang dampak negatif. Selain itu, bimbingan pranikah dan memaksimalkan peran penyuluh agama (PA) untuk mengurangi pernikahan usia dini di kantor urusan Agama (KUA) (Istiqomah, 2018; Munawaroh, 2018). Faktorfaktor yang mempengaruhi pengurangan atau sampai pada pengentasan praktik pernikahan usia dini dengan pemberdayaan masyarakat miskin. Peningkatan kualitas pendidikan khususnya bagi perempuan. Tersedianya lapangan kerja bagi perempuan, terutama usia remaja yang tidak memiliki pekerjaan. Perluanya perluasan jangkauan dan intensitas program BKKBN tentang progam GenRe 
(Generasi Berencana) di beberapa lembaga pendidikan dan lembaga keagamaan (Ketut et al., 2015).

Berbagai program yang dilakukan oleh pemerintah dan swasta untuk mencegah pernikahan usia dini masih belum berjalan maksimal, salah satunya di Provinsi Jawa Timur. Menurut Badan Koordinasi Keluarga Berencana Nasional (BKKBN) angka pernikahan usia dini di Jawa Timur mencapai 3.000 pasangan (BKKBN; 2016). Sumbangan terbanyak dari empat kabupaten yang ada di Madura. Padahal sejak tahun 2010 secara khusus kemen PPPA melakukan upaya dan strategi untuk mengurangi atau mengentaskan kasus pernikahan usia dini di Madura. Salah satu strategi yang dilakukan oleh Kemen PPPA bersama The United Nations Population Fund (UNFPA) melakukan sosialisasi praktik terbaik terkait pencegahan pernikahan usia dini, yaitu dengan memanfaatkan ketokohan kiai di Kabupaten Pamekasan (Laporan, 2018). Akan tetapi, fenomena kasus pernikahan dini masih marak di Kabupaten Pamekasan. Pada tahun 2018 setiap bulan Dinas Pemberdayaan Perempuan Perlindungan Anak dan keluarga Berencana (DP3KB) menerima pengaduan kasus pernikahan usia dini (Musyaffak, 2019).

Riset terdahulu telah menyoroti berbagai hal terkait upaya dan pengentasan pernikahan usia dini, baik dalam struktur pemerintah maupun masyarakat. Dalam kajian tentang pernikahan dini ditemukan empat hal. Pertama, perencanaan sosial terkait pernikahan usia dini masih sangat terbatas. Kajian lebih banyak pada analisis kesehatan atau dari perspektif agama dan hukum. Kedua; Promosi himbauan untuk menikah usia dini belum dikuatkan dengan kajian yang komprehensif secara kependudukan (tidak sebatas KB dan AKI). Ketiga; Kajian dari sisi kependudukan sulit di peroleh terutama dampak dari sisi 
sosial dan ekonomi. Dan yang keempat; isu menikah usia dini belum menyentuh masyarakat desa, sehingga perlu dikaji secara lebih mendalam.

Dalam konteks masyarakat desa, riset tentang peran Klèbun Babine' (kepala desa perempuan) dalam upaya mencegah dan mengentaskan pernikahan usia dini sebagaimana yang ditemukan di Desa Ponteh Kecamatan Galis Kabupaten Pamekasan menjadi penting. Fenomena jumlah pernikahan usia dini dari tahun ke tahun cenderung menurun sesuai dengan data profil desa. Terdapat program khusus dalam pemerintahan yang dilakukan Klèbun Babine', berupa penundaan usia pernikahan. Isu penundaaan usia pernikahan yang terkaitan dengan nasib anak perempuan warga desa menjadi perhatian kepala desa. Dengan data ini, kepala desa perempuan ditemukan memiliki tingkat sensitifitas terhadap persoalan perempuan. Riset ini bertujuan untuk mengungkap peran Klèbun Babine' dalam mengurangi pernikahan usia dini beserta program yang dijalankan oleh Klèbun Babine' dalam mengurangi angka pernikahan usia dini di desa yang dipimpinnya.

Metode penelitian yang digunakan adalah studi kasus (Yin, 2013) dengan pendekatan kualitatif (Creswell, 2009). Dalam pelaksanaannya, pendekatan studi kasus ini memaparkan kasus secara detail dan mendalam peran dan strategi yang dilakukan Klèbun Babine' dalam penundaan usia nikah dini di Desa Ponteh. Informan penelitian terdiri dari aparatur desa bagian pengurusan pernikahan, tokoh masyarakat, perempuan yang akan dinikahkan dan masih dibawah umur dan kepala Desa Ponteh. Data dikumpulkan dengan wawancara mendalam (indept interview) menggunakan guide interview kepala berbagai pihak pemangku kepentingan dan juga juga Focus Group Discussions (FGD) dengan masyarakat serta 
tokoh masyarakat. Observasi juga dilakukan dalam proses pengumpulan data. Setelah data terkumpul, kemudian disusun dan dianalisis sesuai proses melalui reduksi data, penampilan data, verfikiasi, serta kesimpulan (Creswell, 2009).

\section{B. Pembahasan}

Pernikahan usia dini merupakan perkawinan yang dilakukan dibawah usia minimal yang ditetapkan oleh pemerintah. Batas usia minimal yang ditetapkan oleh pemerintah adalah 19 tahun. Pernikahan usia dini merupakan pernikahan yang dilakukan dibawah usia 19 tahun, atau ikatan yang dilakukan oleh remaja laki-laki atau perempuan yang masih dalam usia muda. Ketika seseorang melakukan ikrar batin, baik karena kamauan sendiri ataupun keinginan keluarga. Kegiatan ikrar itu sudah dikatakan sebagai pernikahan. Tujuan dari ikrar batin yang dilakukan baik laki-laki ataupun perempuan dengan tujuan membentuk keluarga baik yang dilakukan secara hukum resmi segara maupun hukum adat (kepercayaan masyarakat) juga dikatakan sebagai pernikahan. Ketika dalam suatu pernikahan tersebut dilakukan oleh seseorang yang memiliki umur yang relatif muda, baik laki-laki ataupun perempuan hal itu dapat dikatakan dengan pernikahanusia dini. Secara jelas, diatur bahwa umur yang relatif muda adalah usia pubertas yaitu usia antara 10-19 tahun. Dengan demikian, seorang remaja yang berusia antara 10-19 tahun yang telah melakukan ikatan lahir batin sebagai seorang suami istri dengan tujuan membentuk keluarga dikatakan sebagai pernikahan usia dini atau pernikahan muda (Desiyanti, 2015, hal. 271).

\section{Kondisi Perempuan di desa Ponteh}

Kondisi perempuan di Desa Ponteh menemui banyak persoalan. Di satu sisi perempuan diperlakukan secara diskriminatif dalam pemenuhan haknya, di lain sisi perempuan di Desa Ponteh dituntut untuk bekerja 
lebih banyak dari pada kaum laki-laki. Kondisi ini berlaku dalam berbagai bidang, mulai dari ekonomi, pendidikan, pekerjaan, hingga penentuan jodoh. Dalam urusan jodoh perempuan selalu pada posisi yang tidak berdaya. Perempuan harus menerima ketentuan dari orang tua, khususnya laki-laki. Otoritas penuh ada pada orang tua laki-laki, sedangkan orang tua perempuan (Ibu) sebagai pertimbangan saja, tidak akan berpengaruh pada keputusan yang dibuat oleh suami. Misal, seperti yang dijelaskan oleh Bunadin (2019) yang memiliki empat anak perempuan;

"saya memiliki anak perempuan, jika ada yang melamar saya tidak akan memikirkan dua dek, selagi ada yang mahu. Takut nanti sampai ta' pajuh lakeh (tidak laku) dek. jadi saya langsung menerima."

Orientasi ini menandakan bahwa perempuan di Desa Ponteh dalam proses perjodohan, baik tunangan sampai pernikahan tidak memiliki nilai tawar sehingga dalam posisi dijadikan objek yang tidak berdaya. Selalu menerima ketentuan yang diputuskan oleh orang tua. Terdapat pandangan masyarakat yang menyatakan bahwa menikah pada usia muda bagi perempuan di Desa Ponteh adalah suatu keharusan dari pada menjadi perawan tua. Pandangan ini menjadi sebuah hukum yang tidak tertulis bagi para orang tua yang memiliki anak perempuan. Ada ketakutan dari orang tua, jika memiliki anak perempuan tidak memiliki jodoh. Masyarakat Desa Ponteh percaya bahwa lebih baik menjadi janda muda dari pada perawan tua (Syam, 2010). Pandangan ini menjadi salah satu penyebab maraknya pernikahan usia dini di Desa Ponteh. Pandangan masyarakat secara langsung berpengaruh terhadap penentuan jodoh dan pelaksanaan usia pernikahan dini di Desa Ponteh.

Selain itu, pandangan masyarakat Desa Ponteh terhadap perempuan juga berpengaruh kepada kesehatan. Kondisi lingkungan masyarakat yang masih lebih 
mengutamakan laki-laki dari pada perempuan berdampak pada kondisi kesehatan perempuan belum memilikijaminan atau setara dengan kaum laki-laki (Zahra, 2014). Beberapa masyarakat Desa Ponteh masih ada yang mempertahankan pandangan tersebut. Salah satu anggapan masyarakat adalah jika laki-laki sebagai kepala keluarga harus selalu sehat dan kuat. Masyarakat menganggap laki-laki yang kuat dianggap menjamin semua anggota keluarga juga akan sehat. Sementara kesehatan perempuan di Desa Ponteh kadang ada yang terabaikan. Sebagai contoh, terjadinya kasus kematian ibu hamil karena kurangnya penanganan dan jaminan kesehatan terhadap kondisi perempuan di Desa Ponteh. Bahkan, sampai saat ini ada beberapa masyarakat Desa Ponteh masih menggunakan jasa dukun beranak dari pada bidan yang sudah ada di desa.

Saat ini, sebagaian besar masyarakat Desa Ponteh sudah mulai menerima pembaruan, khususnya tentang kesehatan perempuan. Meskipun masyarakat Desa Ponteh begitu fanatik terhadap nilai-nilai agama Islam, masyarakat sudah mulai menerima dan terbuka dalam beberapa program pemerintah, salah satunya kelurga berencana (KB) dan beberapa program lainnya (Syamsuddin, 2015) seperti penetapan usia minimal pernikahan. Masyarakat tidak menentang dan cukup apresiatif, meskipun ada sebagin yang menolak karena masih berpegang teguh pada teksteks ajaran agama Islam. Secara keseluruhan, kontruksi budaya yang disematkan pada perempuan di Desa Ponteh ini menjadi salah satu penyebab maraknya pernikahan ini.

Berdarakan data desa, secara umum, penyebab pernikahan usia dini di Desa Ponteh dipengaruhi oleh beberap faktor. Pertama, faktor ekonomi.Sebagian besar masyarakatDesa Ponteh masuk dalam kategori menengah ke bawah (Profil Desa Ponteh, 2018). Menikahkan anak pada usia dini dianggap mampu mengurangi beban ekonomi 
keluarga. Hal ini sejalan dengan studi yang dilakukan oleh UNICEF berbagai faktor dan kompleksitas penyebab pernikahan usia dini, sehingga sulit dicegah terutama untuk negara yang sedang berkembang (Sakdiyah \& Ningsih, 2013). Kedua, fakor diri sendiri. Baik remaja laki-laki atau perempuan mempunyai keinginan sendiri untuk menikah. Ketiga, fakor pendidikan. Sebagain besar masyarakat di Desa Ponteh adalah lulusan SD dan SMP. Pendidikan pesantren masih menjadi pilihan utama oleh masyarakat. Kecenderungan menyekolahkan anak di pesantren dari pada sekolah negeri masih tinggi. Dengan demikian, tafsir yang berkembang dalam pendidikan agama menjadi rujukan tunggal masyarakat, tanpa mempertimbangkan penafsiran lain perihal pernikahan usia dini, misal pesehatan reproduksi, konflik dalam keluarga dan pengasuhan anak. Keempat, Faktor orang tua. Harapan orang tua untuk dapat mencapai keamanan sosial dan finansial. Sehingga pernikahan usia dini merupakan cara ampuh untuk dapat merealisasikan keamanan dan finansial dalam keluarga. Bahkan, menurut pandangan masyarakat di Desa Ponteh, pernikahan usia dini dianggap sebagai sesuatu yang sudah lazim dan tidak melanggar hukum. Bagi sebagian besar masyarakat tolak ukur yang menjadi patokan adalah aqil baligh (sudah cukup umur menurut hukum Islam). Ketika laki-laki atau perempuan sudah aqil baligh makan orang tua cenderung untuk menikahkan putra-putrinya.

\section{Peran Klèbun Babine' bagi Masyarakat Desa Ponteh}

Masyarakat Madura memiliki tingkat kepatuhan yang tinggi terhadap kiai. Selain kiai, kepala desa (Klèbun) menjadi figur, serta menjadi rujukan utama di luar urusan keagamaan (sacred world). Perintah dan larangan dari kepala desa lebih didengar dan dijalankan oleh masyarakat di Desa Ponteh dari pada perintah dari instansi pemerintah 
yang ada diatasnya misalnya camat bahkan bupati sekalipun. Dengan demikian, dalam strata masyarakat di Desa Ponteh, Klèbun menduduki posisi yang paling tinggi. Kepatuhan masyarakat di Desa Ponteh tidak lepas dari ungkapan secara turun temurun dalam masyarakat yaitu "bhuppa' bhabhu' ghuru rato" (bapak, ibu, guru dan raja) (Wiyata, 2006). Bagi masyarakat Desa Ponteh bapak dan ibu adalah sumber utama kepatuhan dalam berbagai bidan baik yang bersifat duniawi dan ukhrowi. Guru secara umum terdapat beberapa makna, yaitu guru sekolah, guru mengaji, guru bekerja dan lain-lain. Tetapi tingkat kepatuhan tertinggi pada ungkapan ghuru disini adalah kiai. Kiai dianggap memiliki ilmu agama, pengetahuan yang mendalam, mengajar kebaikan baik tutur kata dan sikap sehingga menjadi figur bagi masyarakat (Syamsuddin, 2015). Sedangkan rato menurut masyarakat lebih pada pemimpin, yaitu kepala desa.

Desa Ponteh dipimpin oleh perempuan (Klèbun Babine'). Pengakuan kapasitas dan kapabilitas Klèbun Babine' bagi masyarakat Desa Ponteh setara dengan pengakuan atas kemampuan kepala desa laki-laki yang lazim di desa lain. Hal ini terlihat dalam pemaparan dari ibu Ika, salah satu tokoh masyarakat perempuan di Desa Ponteh:

"Ibu Nansi bekerja tidak kalah bedanya dengan kepala
desa laki-laki. Bahkan beliau selalu siap siaga, kalau ada
apa-apa langsung berhubungan dengan beliau, khususnya
bidang kemasyarakatan"

Istilah yang muncul dalam masyarakat "mon bhedeh pa'apaan paggun Kalebunah sebedeh éadhe'" (kalau ada apaapa pasti kepala desa yang ada didepan). Ungkapan ini terdapat beberapa makna, mulai kegiatan yang berhubungan dengan pemerintahan, atau pembangunan masyarakat kepala desa selalu ada di depan. Sampai kifaye (meninggal dunia) kepala desa selalu ada 24 jam. Saat ada 
masyarakat yang terjerat kasus hukum, kepala desalah yang pertama mengurus masyarakatnya. Kedekatan inilah yang menjadi salah satu faktor masyarakat Desa Ponteh begitu menghormati Klèbun Babine'. Dalam teori peran dari perspektif Sosiologi, individu dikontruksi tentang bagaimana dia dapat menjalankan fungsi sesuai kapasitas dan kapabilitasnya (Suhardono, 1994, 1). Berkaitan dengan Klèbun Babine', fungsi dan status yang dibawa dalam lingkungan sosial dan struktur sosial di Desa Ponteh. Klèbun Babine' menjalankan perannya sesuai dengan status pada struktur sosial yang ada dalam masyarakat dengan memaksimalkan peran tersebut dalam mengurangi atau dapat mengentaskan kasus pernikahan usia dini di desa yang dipimpinnya. Peran Klèbun Babine' sebagai seorang aktor dibatasi oleh aktor lain sehingga terwujud saling ketergantungan. Dalam konteks sosial, tidak ada satupun peran dapat berdiri sendiri tanpa ada peran yang lain (Suhardono, 1994, 4).

Dalam menjelaskan teori peran Klèbun Babine' ini, ada dua pendekatan yang dapat digunakan yaitu melalui pendekatan strukturalis dan pendekatan interaksionis. Pendekatan struktualis lebih menempatkan peran sebagai sebuah bagian dari kultural yang ada serta peran tersebut mengacu pada hak dan kewajiban yang sudah ada dan ditetapkan serta disepakati oleh sistem budaya. Pada sistem budaya ini peran sudah disediakan oleh sistem posisional. Kemudian merujuk pada suatu bagian dari struktur sosial yang ada dalam masyarakat. Penerapan dari pendekatan strukturalis ini adalah dapat dilihat dari sistem pemerintah dan pengelolaan suatu desa. Top manajer adalah kepala desa yaitu Klèbun Babine' melakukan perencanaan, pelaksanaan, pengkoordinasian dan pengendalian dalam pemerintahan desa. Peran Klèbun Babine' sudah dibentuk oleh struktur sosial yang sudah ada. Sedangkan pendekatan interaksionis 
merupakan interaksi dari fenomena peran yang ada. Peran bagi Suhardono (1994) merupakan suatu bentuk (role enactment) yang diibaratkan seperti organis.Individu pelaku peran berusaha untuk selalu menampilkan "mumpuni" atau sesuai dengan kondisi lingkungan masyarakat dimana aktor tersebut menjalani peran. Kesesuaian ini dipersepi oleh pelaku lainnya sebagai aktor yang menjalankan peran "tidak menyimpang" dari sistem sosial masyarakat yang ada.

Dalam konteks masyarakat Desa Ponteh, peran individu dalam lingkungan masyarakat disesesuaikan dengan kedudukan dan jabatan yang dimilikinya. Dalam menjalankan tugas dan fungsinya, Klèbun Babine' menjalankan peran dengan baik. Terkait dengan peran Klèbun Babine'dalam mengurangi atau mengentaskan kasus pernikahan usia dini di Desa Ponteh begitu terlihat. Selain dilihat dari konsep peran, perogram penundaan pernikahan usai dini yang dilakukan Klèbun Babine' juga dilihat dari teori Berger. Hubungan antara Klèbun Babine' sebagai figur pemimpin sebuah pemerintahan desa dan masyarakat (khususnya pemangku kepentingan pernikahan usia dini). Hubungan antara Klèbun Babine' dan masyarakat dalam mengkontruksi budaya/subkultur dalam penundaan pernikahan usia dini menarik jika dilihat dari kerangka teori Peter L. Berger yang dikutip oleh Ulyani (2014) melihat relasi individu dengan masyarakat melalui tiga momen dialektis yaitu eksternalisasi, obyektifikasi dan internalisasi.

Menurut Berger dalam Ulyani (2014) melalui eksternalisasi ini, individu dapat mengekpresiakan diri dalam membangun dunianya. Pengungkapan ini dapat mewujudkan suatu realitas yang obyektif setelah melakukan suatu proses yang dinamakan obyektifikasi. Begitu juga dengan realitas obyektif juga akan berpengaruh 
kuat terhadap pembentukan prilaku individu. Proses ini dapat berjalan optimal setelah individu melewati suatu tahap internalisasi. Dengan perspektif ini, proses sosial kontruksi budaya dalam perogram penundaan pernikahan usia dini oleh Klèbun Babine 'tidak lepas dari interaksi dialektis figur kunci yaitu kepala Desa Ponteh. Kesadaran kognitif diekspresikan dalam bentuk ceramah, diskusi, penampilan, tulisan dan berbagai kegiatan lain. wacana yang disampaikan kepala Desa Ponteh melalui berbagai kegiatan dengan bermacam metode secara bertahap akan mengkontruksi berbagai pengetahuan baru tentang dampak negatif dari pernikahan usia dini. Dengan demikian, secara tidak sadar, jika kegiatan tersebut dilakukan secara terus-menerus proses internalisasi program tersebut sedikit banyak akan mempengaruhi pola pikir dan sikap masyarakat terhadap pernikahan usia dini.

\section{Upaya Klèbun Babine' dalam Pencegahan Pernikahan Usia Dini}

Bagi masyarakat Desa Ponteh, "lebbhi partajeh ngabes bhukteh etembeng gun ngiding caretah.Makehla deri presiden" (lebih percaya melihat bukti, dari pada hanya mendengar informasi, meskipun itu adalah intruksi langsung dari presiden). Ungkapan ini masih dipegang teguh oleh masyarakat hingga saat ini. Masyarakat Desa Ponteh masih menjunjung adat dan kepercayaan melihat langsung bukti kongrit, dari pada program yang akan dilaksanakan dan masih sebatas wacana. Meskipun program tersebut dari presiden sekalipun. Salah salah satu bukti konkrit adalah sosok perempuan yang menjadi Klèbun. Sehingga peran Klèbun Babine' dalam menjalankan program menjadi lebih diterima oleh masyarakat, khususnya terhadap program yang berhubungan dengan perempuan, yaitu penundaan pernikahan usia dini. Seperti penjelasan dari Ibu Ika (2019), 
“Bu Nansi menjadi kepala desa, menjadikan remaja perempuan lebih tertantang. Jika didepan kita ada perempuan yang sanggup menjadi pemimpin. ini berdampak bagus, karena figur perempuan yang menjadi Klèbun dapat dicontoh oleh remaja perempuan yang ada di Desa Ponteh"

Selain berfungsi sebagai kepala pemerintahan, pemberdayaan masyarakat, bagi sebagian besar perempuan remaja di Desa Ponteh Klèbun Babine' dijadikan figur perempuan yang dapat dicontoh untuk menjadi perempuan yang sukses. Sukses menurut pendangan masyarakat adalah seimbang antara peran publik dan domestik. Disatu sisi, perempuan menjalani peran publiknya menjadi Klèbun dan perempuan dapat mengelola rumah tangga dengan baik.

Berdasarkan hasil wawancara mendalam dengan Klèbun Babine'di Desa Ponteh, terdapat beberapa upaya penundaan usia nikah muda. Pertama, peran aktif Klèbun Babine', karena program ini merupakan agenda yang digagas sendiri oleh kepala desa.seperti penjelasan ibu Nansi (2019),

“Program perempuan, Kalau program yang khusus untuk perempuan saya itu memang membuat kebijakan sendiri (sebenarnya bukan inisiatif sendiri, tapi melanjutkan program pemerintah) tapi ini memang menjadi salah satu agenda saya ketika menjadi kepala desa. Yaitu program untuk penundaan usia nikah bagi perempuan. Karena memang nasib sesama perempuan itu sangat memprihatinkan. Alhamdulilah sejak dua tahun terakhir ini Desa Ponteh sudah bebas dari pernikahan usia muda, khususnya bagi perempuan"

Alasan Klèbun Babine' mengagas program ini adalah karena sudah paham dan sadar dengan dampak negatif dari pernikahan usia dini. Untuk itu, Klèbun Babine' membuat aturan ketat dengan melarang aparatur 
memberikan rekomenkasi dari desa, jika anak tersebut memang masih berada dibawah umur sesuai batas minimal yang ditetapkan pemerintah yaitu 19 tahun. Setelah itu pendekatan dilakukan kepada orang tua yang bersangkutan. Klèbun Babine' menanyakan langsung motif yang menjadi dorongan utama menikahkan anak perempuannya. Saat dilakukan pendekatan, anak tersebut ternyata tidak ingin dinikahkan. Dia ingin melanjutkan pendidikan sampai perguruan tinggi. Setelah lulus kuliah, harapannya mendapat pekerjaan tetap di kota (Kabupaten Pamekasan). Bahkan menurut pemaparan orang tua remaja gadis, menikahkan anaknya saat ini bukan ide nya sendiri. Saat dilakukan pendekatan secara komprehensif oleh Klèbun Babine' orang tua gadis ini memaparkan bahwa yang memaksa untuk menikahkan adalah pamannya. Sementara orang tua dari perempuan tersebut masih ingin melihat anak perempuannya melanjutkan sampai keperguruan tinggi. Harapan dari orang tua remaja perempuan ingin anaknya mampu sekolah lebih tinggi, serta memiliki pekerjaan yang lebih baik dari saat ini.

Kedua, Klèbun Babine' melakukan pendekatan secara multidimensional sebelum menentukan kebijakan yang tepat untuk penundaan pernikahan usia dini. Mengingat kompleksitas penyebab pernikahan usia dini di Desa Ponteh. Peran ini dapat ditemukan ketika Klèbun Babine' melakukan pendekatan dari berbagai aspek. Pendekatan dimulai dari mengubah mind set masyarakat dari pandangan agama dimana Klèbun Babine' aktif melakukan pendekatan secara personal dengan kiai dan nyai (baik sebagai istri kiai maupun secara pribadi sebagai tokoh agama perempuan). Kiai dan nyai memiliki pengaruh yang kuat dalam memobilisasi (mengarahkan, melarang) masyarakat Desa Ponteh. Selain sebagai rujukan utama dalam hal keagamaan, kiai dan nyai merupakan panutan 
dalam penentuan nama anak, acara pernikahan serta beberapa kegiatan warga lainnya. Strategi penyadaran dari perspektif agama, kiai dan nyai dianggap cukup ampuh oleh Klèbun Babine' dalam menentukan kebijakan untuk menunda pernikahan usia dini. Upaya ini senada dengan penjelasan Rifai (2019), pandangan dan sikap kiai atau dai atas realitas pernikahan usia dini menjadi penting. Tokoh agama ini menjadi sumber pemahaman bagi masyarakat tentang pengurangan perjodohan dini. Tokoh masyarakat, lebih fokus terhadap penyadaran budaya masyarakat, terutama pernikahan dibawah umur. Posisi tawar dari Klèbun Babine' menjadi lebih tinggi dalam masyarakat karena Klèbun Babine' dapat menjadi contoh, jika perempuan dapat sukses bekerja di luar rumah,tidak mesti perempuan berfungsi untuk urusan rumah tangga saja.

Ketiga, Klèbun Babine' melakukan penyadaran kepada masyarakat dengan memanfaatkan berbagai kegiatan desa. Bentuk penyadaran yang dilakukan oleh Klèbun Babine' di Desa Pontehadalah pentingnya pendidikan, khususnyabagi remaja perempuan. Salah satu agenda pendidikan ini adalah dengan program dalam satu rumah tangga harus terdapat sarjana. Program ini dijalankan secara berkelanjutan. Klèbun Babine' selalu menanyakan kepada para pamong (ketua RT) tentang kondisi pendidikan masyarakat di tiaptiap kampungnya.Saat ada masyarakat yang mempunyai siswa atau mahasiswa, Klèbun Babine' selalu memberikan motivasi kepada orang tua untuk melanjutkan pendidikan putra/putrinya sampai pendidikan yang paling tinggi. Meskipun program ini tidak dianggarkan dalam dana desa, terkadang Klèbun Babine' memberikan bantuan uang untuk menunjang pendidikan remaja di Desa Ponteh, misal; untuk membeli buku, tas dan perlengkapan sekolah lainnya. Program satu rumah satu sarjana ini diharapkan dapat meningkatkan pengetahuan serta wawasan dalam 
berbagai hal seperti sanitasi, keuangan, pajak, peraturanperaturan desa, pekerjaan, pendidikan serta kesehatan reproduksi remaja.

Keempat, sosialisasi tentang kesehatan reproduksi remaja secara terpadu. Klèbun Babine' secara intensif melakukan kegiatan penyuluhan. Kegiatan penyuluhan ini dilakukan dua kali dalam satu tahun. Berbagai instansi terkait dilibatkan, mulai dari puskesmas sampai Dinas Kesehatan Kabupaten Pamekasan. Dalam setiap kegiatan penyuluhan, Klèbun Babine' selalu terlibat aktif mulai dari persiapan, pelaksanaan sampai acara selesai. Tempat kegitan penyuluhan tentang kesehatan reproduksi remaja bermacam-macam. Panitia penyelenggara yaitu aparatur desa menyesuaikan diri dengan kondisi masyarakat di Desa Ponteh. Dari pemaparan aparatur desa, bapak Jufriadi (2019) yang bertugas menyiapkan tempat penyuluhan menjelaskan,

“Bu Nansi memang gencar melakukan kegiatan penyuluhan ini, kadang beliau ketika tidak ada kabar dari penyuluh Puskesmas, langsung didatangi ke lokasi. Untuk lokasi pelaksanaan penyuluhan itu kondisional, menyesuaikan dengan keadaan masyarakat Desa Ponteh dek.."

Kegiatan penyuluhan tentang kesehatan reproduksi remaja di Desa Ponteh beberapa kali dilakukan di balai desa, di sekolah-sekolah dan tempat kerumunan warga lainnya seperti arisan juga disempatkan melakukan sosialsisasi. Selain arisan, lazimnya saat ada kompolan (pengajian muslimat) juga dilakukan kegiatan sosialisasi.Tujuan dengan menggunakan acara arisan warga dan kompolan sebagai tempat sosialisasi karena masyarakat Desa Ponteh sulit untuk dikumpulkan dalam acara resmi. Sulitnya masyarakat Desa Ponteh untuk dikumpulkan dalam acara resmi karena mayoritas bekerja sebagai petani, buruh 
tani dan penyedia jasa. Bagi petani, berangkat ke sawah atau ladang pagi sesudah shalat subuh kemudian pulang sore sebelum salat Magrib. Begitu juga bagi buruh tani. Sedangkan masyarakat yang bekerja di sektor jasa seperti penjaga warung makanan, bekerja di gudang penimbunan tembakau, jasa pengiriman barang sebagian besar kerja sehari penuh. Jarang ada libur tetap bagi masyarakat yang bekerja dibidang penyedia jasa. Oleh karen itu, Klèbun Babine' sulit untuk mengumpulkan warga masyarakat dalam satu acara resmi.

Program penundaan nikah usia dini di Desa Ponteh yang dilaksanakan oleh Klèbun Babine' berjalan sukses. Berdasarkan data pernikahan yang terdaftar di administratif desa, sejak 5 tahun terakhir mengalami penurunan sebagaimana dalam grafik berikut:

\section{Grafik Pernikahan Usiadini di Desa Ponteh dalam 5 Tahun Terakhir}

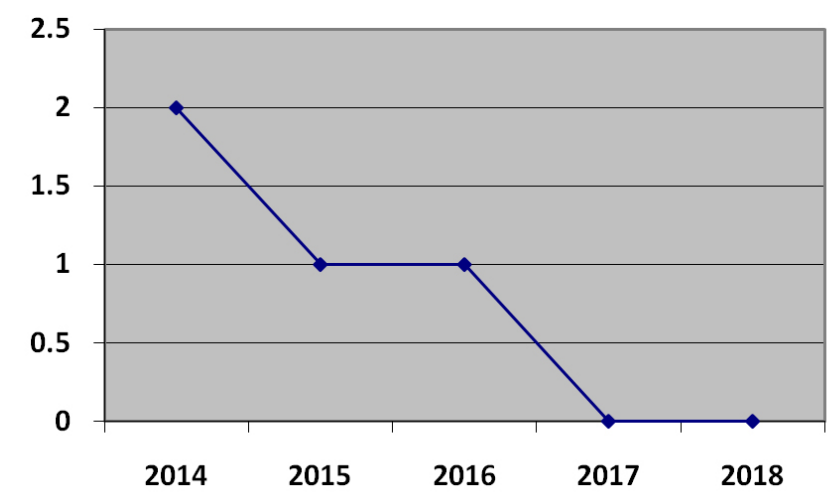

Gambar 1: Data diolah dari administratif Desa Ponteh tahun 2018

Dari grafik di atas, menunjukan penurunan angka pernikahan usia dini. Dari tahun 2014 yang tercatat dalam data administratif Desa Ponteh sebanyak dua orang remaja perempuan yang menikah di usiadini. Pada tahun 
selanjutnya di tahun 2015 dan 2016 terdapat satu remaja perempuan yang menikah di usia dini. Sedangkan pada tahun 2017 dan 2018 tidak ada remaja perempuan menikah dibawah usia minimal yang ditetapkan oleh pemerintah. Dari penejelasan Klèbun Babine', terdapat perubahan baru dalam orientasi kehidupan keluarga, dimana masyarakat Desa Ponteh sebagian besar sudah sadar dampak dari pernikahan usia dini. Terutama dampak negatif yang dialami oleh perempuan.

Berbagai upaya yang dilakukan Klèbun Babine' untuk mencegah kasus pernikahan usia dini berjalan optimal. Upaya pencegahan pernikahan dini yang dilakukan oleh Klèbun Babine' secara normatif dilakukan dengan membuat aturan menolak memberikan rekomendasi dari desa untuk anak dibawah umur. Penolakan ini memang dapat berdampak positip dan negatif. Dampak positifnya adalah program penundaan usia nikah bagi remaja berjalan sesuai harapan. Tetapi dampak negatifnya muncul gunjingan dalam masyarakat bahwa kepala desa diangap menghalangi proses pengurusan pernikahan yang dianjurkan oleh agama. Kedua,Klèbun Babine'melakukan pendekatan secara multidimensional sebelum menentukan kebijakan yang tepat untuk penundaan pernikahan usiadini. Karena setiap kasus pernikahan usia dini memiliki penyebab yang berbeda. Dengan demikian, menurut Klèbun Babine' harus dipelajari terlebih dahulu setiap kasus penyebab pernikahan usia dini. Setelah itu menentukan program apa yang paling tepat untuk menunda pernikahan usia dini. Ketiga, Klèbun Babine' melakukan penyadaran kepada masyarakat dengan memanfaatkan berbagai kegiatan desa. Mengingat sulitnya masyarakat untuk dikumpulkan dalam suatu acara resmi. Hal ini disebabkan oleh masyarakat yang banyak bekerja sebagai buruh tani, penjaga warung, jasa dan lainnya. Sehingga Klèbun Babine' menggunakan 
media arisan, pengajian perempuan muslimat (kompolan) sesekali dilakukan kegiatan sosialisasi tentang penundaan pernikahanusiadini. Keempat, sosialisasi tentang kesehatan reproduksi remaja secara terpadu. Kepala desa bekerja sama, baik dengan dinas kesehatan Kabupaten, puskesmas, tokoh masyarakat.

Selain upaya yang dilakukan Klèbun Babine', bentuk partisiapsi masyarakat dalam penundaan dan pencegahan pernikahan usia dini bagi remaja perempuan di Desa Ponteh berjalan dengan berberapa strategi. Pertama, perempuan bekerja di luar rumah (sebagai penjaga toko, buruh rokok, mengajar, kerja di kantoran baik swasta ataupun pegawai negeri sipil) dan mempunyai penghasilan yang tetap. Perempuan yang telah bekerja dan hendak dinikahkan oleh orang tua dalam usia dini maupun perjodohan yang tidak diinginkan maka perempuan remaja di Desa Ponteh dapat menolak dengan alasan pekerjaan. Dengan bekerja, remaja perempuan di dalam masyarakat Desa Ponteh menemukan cara untuk menciptakan posisi yang mampu dan berdaya. Kondisi ini akan mendapat pengakuan dari orang tua dan masyarakat setempat. Posisi perempuan mempunyai nilai tawar yang lebih tinggi, yaitu dapat menolak ketika dijodohkan dan dinikahkan oleh orang tua secara paksa baik ketika belum cukup usia (pernikahan usia dini) maupun telah memenuhi.

Kedua, melalui pendidikan. Para remaja perempuan di Desa Ponteh setelah mereka menyelesaikan pendidikan. Saat ini, sebagian besar pendidikan masyarakat masih SD dan SMP. Sebagai hasil, temuan yang disajikan di sini menyiratkan bahwa perempuan yang pendidikannya lebih tinggi banyak hal yang lebih dipertimbangkan, salah satunya adalah memikirkan masa depan. Terlihat pada kalangan perempuan yang melanjutnya perguruan tinggi di Desa Ponteh, banyak dari mereka yang membangun 
karir. Sehingga menurunkan peluang bagi perempuan muda untuk menikah atau dipaksa untuk menikah, baik oleh orang tua atau kerabat. Dalam masyarakat Desa Ponteh, selain orang tua, yang menentukan hak mutlak dalam penentuan perjodohan dan perkawinan seorang anak adalah kerabat dekat misal; paman, kakek. Solusi yang ditawarkan untuk mengurangi pernikahan usia dini dengan melakukan intervensi yang efektif. Intervensi dimulai dari komunitas terkecil yaitu keluarga. Keluarga ditumbuhkan kesadaran tentang konsekuensi negatif dari pernikahan usia dini.

\section{Simpulan}

Klèbun Babine' di Desa Ponteh Kecamatan Galis Kabupaten Pamekasan tidak hanya berfungsi sebagai administratif, manajerial atau sosial kemasyarakatan melainkan juga menjadi figur yang dapat di contoh untuk meretas budaya pernikahan usiadini yang merugikan perempuan di pedesaan. Munculnya perempuan sebagai kepala desa dapat memudahkan penyadaran yang dilakukan oleh pemerintah sehingga penundaan usia nikah dapat memaksimalkan perempuan untuk dapat melanjutkan pendidikan yang lebih tinggi ataupun bekerja di sektor produktif. Klèbun Babine' dalam mengentaskan pernikahan usia muda di Desa Ponteh Kecamatan Galis Kabupaten Pamekasan melakukan berbagai strategi dimulai dari menciptakan regulasi, edukasi dan sosialisasi baik memanfaatkan kegiatan dalam pemerintahan desa maupun kegiatan kemasyarakatan.

Model pencegahan Klèbun Babine' dalam pencegahan usia dini di masyarakat desa dapat dijadikan model bagi kementerian atau dinas terkait baik oleh Kementrian Pemberdayaan Perempuan dan Perlindungan Anak (KEMENPPPA) untuk mengurangi angka pernikahan 
usia dini di Madura. KEMNPPA dapat memaksimalkan peran kepala desa di Madura. Peran kepala desa dapat bersinergi dengan program pemerintah dalam pencegahan kasus pernikahan usia dini sehingga berjalan maksimal. Strategi budaya ini dapat dilakukan sesuai dengan konteks masyarakat Madura dimana peran kepala desa sangat sentral dalam menentukan cara pandang masyarakat. 


\section{DAFTAR PUSTAKA}

Creswell, J. W. (2009). Qualitative Inquiry and Research Design: Choosing Among Five Tradition. Bandung: Pendidikan IPS Universitas Pendidikan Indonesia.

Desiyanti, I. W. (2015). Faktor-Faktor yang Berhubungan Terhadap Pernikahan Dini Pada Pasangan Usia Subur di Kecamatan Mapanget Kota Manado. IKMU, 5(2).

Farida, U. (2014). Politik Kepemimpinan Pesantren: Peran publik perempuan di pesantren Daarut Tauhiid Bandung. PALASTREN, 7(2). https://doi.org/ http:/ / dx.doi.org/10.21043/palastren.v7i2.1033

Herman, D., \& Sarinah. (2018). Peranan Pemerintah dan Partisipasi Masyarakat terhadap penanggulangan Pernikahan dini di Kecamatan Pitu Riawa Kabupaten Sidenreng Rappang. Stienobel Indonesia, 04(02).

Ika, S. (2019). Wawancara Pribadi. Pamekasan.

Istiqomah, N. (2018). Peran Penyuluh Agama (PA) dalam Meminimalisir Pernikahan di KUA Kecamatan Dawe Kabupaten Kudus. Institut Agama Islam Negeri Kudus.

Jufriadi. (2019). Wawancara Langsung. Pamekasan.

Kabang, M., Trisnowati, E., \& Tri, M. R.S. (2018). Pemahaman tentang akibat pernikahan di bawah umur melalui layanan informasi dengan teknik diskusi. Bimbingan dan Konseling Ar-Rahman, 4(2). https:// doi.org/:/ / dx.doi.org/10.31602/jbkr.v4i2.1504

Ketut, S. I., A, M. D. I. G., \& Nyoman, D. R. I. (2015). Faktorfaktor yang mempengaruhi menurunnya Usia Kawin Pertama di Provinsi Bali. Piramida, 11(2). 
Laporan. (2016). Persentase Perempuan Jawa Timur Usia 10 Tahun Ke Atas yang Kawin di Bawah Umur (Kurang dari 17 Tahun) menurut Kabupaten/Kota, 2009-2016.

Laporan. (2018). Strategi pencegahan perkawinan anak dirumuskan. Kementerian Pemberdayaan Perempuan dan Perlindungan Anak Republik Indonesia.

Mulia, S. M. (2018). 5 alasan mengapa perkawinan anak harus dilarang.

Munawaroh, E. (2018). Bimbingan Pranikah dengan kasus pernikahan dini di KUA Kecamatan Tirtomoyo Kabupaten Wonogiri. Institut Agama Islam Negeri Surakarta.

Musyaffak. (2019). Kasus Pernikahan Dini Masih Marak di Pamekasan.

Nansi, P. (2019). Wawancara Langsung. Pamekasan.

Sakdiyah, H., \& Ningsih, K. (2013). Mencegah Pernikahan Dini untuk Membentuk Generasi Berkualitas Previnting Early-age Marriage to Estabilish Qualified Generation). Masyarakat, Kebudayaan dan Politik, 26(1).

Salim, A. (2018). Persoalan di Balik Tingginya Angka Perkawinan Anak Indonesia.

Suhadi, S., Baidhowi, B., \& Cahya, W. (2018). Pencegahan Meningkatnya Angka Pernikahan Dini dengan Inisiasi Pembentukan Kadarkum di Dusun Cemanggal Desa Munding Kecamatan Bergas. Pengabdian Hukum Indoneisia, 1(1).

Suhardono, E. (1994). Teori Peran (Konsep, derivasi dan implikasinya). Jakarta: Gramedia Pustaka Utama.

Syam, N. (2010). Pendidikan Bagi Kaum Perempuan. 
Syamsuddin, M. (2015). Elit Lokal Madura: Sisi Kehidupan Kaum Blater. Jurnal Lektur Keagamaan, 13(1). https:/ / doi.org/http://dx.doi.org/10.31291/jlk.v13i1.208

Wiyata, A. L. (2006). Carok Konflik Kekerasan dan Harga Diri Orang Madura. Yogyakarta: LKiS.

Yin, R. K. (2013). Studi Kasus Desain \& Metode. Jakarta: Rajawali Press.

Zahra, F. (2014). Peran Publik Perempuan dalam Parlemen (Studi Analisis Representasi Wakil Rakyat Perempuan dalam Lintas Sejarah Indonesia). PALASTREN, 4(2). https://doi.org/10.21043/ palastren.v7i2.1015 
